\title{
Elimination of the Crown Gall Pathogen, Agrobacterium vitis, from Systemically Infected Grapevines by Tissue Culture
}

\author{
Luz Marcela Yepes, ${ }^{1}$ Tom Burr, ${ }^{1}$ Cherie Reid, ${ }^{1}$ and Marc Fuchs ${ }^{1 *}$
}

\begin{abstract}
Agrobacterium vitis causes crown gall, a serious disease of grapevines that is common in grape growing regions worldwide. Tissue culture approaches were previously tested for elimination of the bacterium from grapevines, but the detection methods for assessing their effectiveness were much less sensitive than the recently developed magnetic capture hybridization real-time PCR. The latter method was applied in this study to evaluate the elimination of $A$. vitis from cuttings propagated from severely crown gall-diseased Vitis vinifera cv. Riesling vines by dissecting and culturing apical and axillary buds, as well as meristems, from shoot tips and micropropagating them in tissue culture to recover plantlets. Although the distribution of $A$. vitis in infected mother vines varied greatly, apparently bacteria-free meristematic tissues were successfully used for the establishment of vines for which bacterial populations were undetectable, even after a dormancy period. It is anticipated that the production and use of clean grapevines in vineyards will delay the early onset of crown gall and contribute to vineyard productivity.
\end{abstract}

Key words: Agrobacterium vitis, crown gall, micropropagation, sanitation, tissue culture, Vitis vinifera

Crown gall caused by Agrobacterium vitis is a serious bacterial disease in vineyards on a global scale. Due to the lack of host resistance, particularly in high-quality Vitis vinifera winegrapes, attempts to manage the disease consist of cultural practices to reduce vine injuries that serve as infection entry sites for the pathogen (Moyer and Grove 2014, Burr et al. 2016, Kuzmanović et al. 2018). Vineyard site selection with well drained soils and good air circulation is important for the vines to be less prone to injury from freezing temperatures; such injury stimulates crown gall formation in infected plants (Moyer and Grove 2014, Burr et al. 2016, Kuzmanović et al. 2018). Indeed, crown gall is often most prevalent in low-lying regions of vineyards that may accumulate water and where cold air settles in frost pockets. Similarly, overly wet soil conditions can affect late-season vine acclimation, making them more prone to injury from sudden freezing tempera-

${ }^{1}$ School of Integrative Plant Science, Section of Pathology and Plant-Microbe Biology, Cornell University, New York State Agricultural Experiment Station, Geneva NY 14456.

*Corresponding author (mf13@cornell.edu; tel: 315787 2487; fax: 317789 2389)

Acknowledgments: The authors are grateful to Barbara Collins-DeHaven and Cheung Yen Mei for excellent care of the plants in the greenhouse and to Elizabeth Cieniewicz for assistance with the Olympus SZX16 stereo microscope. This work was supported in part by a grant from USDA-APHIS National Clean Plant Network (16-8130-0429-CA).

Manuscript submitted Oct 2018, revised Dec 2018, accepted Jan 2019

Copyright $(2019$ by the American Society for Enology and Viticulture. All rights reserved.

By downloading and/or receiving this article, you agree to the Disclaimer of Warranties and Liability. The full statement of the Disclaimers is available at $\mathrm{http}: / / \mathrm{www}$.ajevonline.org/content/proprietary-rights-notice-ajev-online. If you do not agree to the Disclaimers, do not download and/or accept this article. doi: 10.5344/ajev.2019.18083 tures (Moyer and Grove 2014, Burr et al. 2016, Kuzmanović et al. 2018). Where possible, management of irrigation water is another practice employed for slowing vine growth in late season to facilitate hardening-off of vines, thereby making them less prone to winter freezes. Factors that adversely affect vine sensitivity to freezing temperatures and injury include excessive fertilization and overcropping, which may stimulate late-season growth and impact winter hardiness (Moyer and Grove 2014, Burr et al. 2016, Kuzmanović et al. 2018). In cold-climate regions, the practice of hilling soil around grafts in the fall is employed as a means of protecting the graft union against winter freezes in locations were the bacterium is present (Moyer and Grove 2014). If freeze events severely damage or kill vine trunks, it becomes possible to train a new trunk the following year that is generated from the remaining buried living scion wood. The training of multiple trunks per vine is commonly implemented as well. Once a trunk becomes injured and diseased with crown gall, it is removed and the remaining trunk or trunks will allow crop production while new trunks are trained.

There are no effective chemical controls for crown gall (Moyer and Grove 2014, Burr et al. 2016, Kuzmanović et al. 2018). Although antibacterial compounds, such as copper products, are lethal to $A$. vitis, topical treatments to vines do not affect the bacterium surviving systemically (Moyer and Grove 2014, Burr et al. 2016). The use of hot-water treatment of dormant cuttings was evaluated for crown gall disease management (Burr et al. 1989, Bazzi et al. 1991). Submersing cuttings in water at $50^{\circ} \mathrm{C}$ for 30 min greatly reduced, but did not eliminate, populations of the pathogen (Burr et al. 1996). With temperatures higher than $50^{\circ} \mathrm{C}$, the potential for increased bud mortality is apparent, although dormant cuttings collected from specific locations in Washington State could withstand higher temperatures without bud kill (Wample et 
al. 1991). Despite the fact that hot water treatment may result in a certain amount of bud kill, the practice $\left(50^{\circ} \mathrm{C}\right.$ for $\left.30 \mathrm{~min}\right)$ is used in some regions and felt to be of value as a crown gall management tool.

The discovery that $A$. vitis survives systemically in grapevine propagation material (Burr et al. 1988, 2016, Kuzmanović et al. 2018) stimulated research to determine if vines that are free of the pathogen may be produced. Therapeutics using tissue culture approaches have been employed to eliminate viral and bacterial pathogens from plants, including grapes (Dula et al. 2007, Cassells 2012, Golino et al. 2017). Explants (from shoot tips to meristems) are cultured in specific tissue culture media to facilitate development and growth while eliminating pathogens, in some instances in combination with thermotherapy and chemotherapy (Sim and Golino 2010, Maliogka et al. 2014, Golino et al. 2017). Shoot tip culture was previously tested and shown to be effective for elimination of $A$. vitis (Burr et al. 1988); however, the detection method for evaluating its effectiveness was much less sensitive than the magnetic capture hybridization in conjunction with real-time PCR (MCH-qPCR) currently in use (Johnson et al. 2013).

The MCH-qPCR method was developed and employed in our laboratory to further our understanding of the presence of $A$. vitis in association with grapevines. It is a highly sensitive method that detects as few as 10 cells/sample (Johnson et al. 2013). Briefly, grapevine tissue is cut in $0.5-\mathrm{cm}$ pieces, incubated in phosphate buffer saline, and subjected to a vacuum to facilitate the release of bacteria cells from xylem vessels. The solution is then incubated for three days at $28^{\circ} \mathrm{C}$ in nutrient broth supplemented with cycloheximide $(100 \mathrm{mg} / \mathrm{L})$ for DNA extraction from $A$. vitis cells with beads conjugated with a biotinylated capture probe flanking the target virD2 sequence. The isolated DNA is subsequently used in qPCR (Johnson et al. 2013).

Since MCH-qPCR is based on the amplification of a conserved region of the virD2 gene (an essential gene for tumorigenicity that is located on the Agrobacterium Ti plasmid), it detects only the presence of tumorigenic strains of the pathogen. The method thus far has been utilized to study the distribution of $A$. vitis in grapevines (Johnson et al. 2016) and its presence in Vitis riparia and other wild grapes in New York and California (Orel et al. 2017). The bacterium was found by MCH-qPCR to be randomly distributed in dormant canes from severely infected $V$. vinifera $\mathrm{cv}$. Riesling vines, and from green shoots and shoot tips from multiple grape cultivars (Johnson et al. 2016). We aimed to utilize this more specific and sensitive method to evaluate the elimination of $A$. vitis using tissue culture following the isolation and micropropagation of apical and axillary buds, as well as meristems from shoot tips of crown gall-infected $V$. vinifera $\mathrm{cv}$. Riesling vines.

\section{Materials and Methods}

Source wood selection. Dormant symptomless cuttings of $V$. vinifera cv. Riesling were collected in January 2013 from vines showing severe crown gall in a vineyard in the Finger
Lakes region of New York. Three-node cuttings were callused by making a slanted cut through the basal node, followed by planting in moistened perlite for about four to five weeks, at which time roots and short shoots (two to four leaves) developed. Rooted cuttings were then planted in Cornell mix (a mixture of peat, vermiculite, ground limestone, and Uni-Mix 10-20-5) in pots in the greenhouse for pathogen detection assays and pathogen elimination experiments.

Tissue culture protocols for $\boldsymbol{A}$. vitis elimination. To examine $A$. vitis elimination, shoot tip explants $(2$ to $3 \mathrm{~cm}$ in length) of actively growing potted $V$. vinifera cv. Riesling vines were collected at different times in 2015, as bacterial distribution is not uniform and some meristematic tissues are pathogen-free (Johnson et al. 2016). Large leaves were removed using scissors, and explants were surface disinfected for establishment in tissue culture, as previously described (Alzubi et al. 2012). Leaves and petioles were removed using a scalpel, and only leaf primordia were left. Apical and axillary buds with adjacent stem tissue $(\sim 0.5 \mathrm{~cm}$ in length), as well as meristems $(0.3$ to $0.5 \mathrm{~mm})$, were dissected under a stereoscope in sterile water containing $74 \mathrm{mg} / \mathrm{L}$ cysteine, then rinsed in sterile water containing carbenicillin $(1 \mathrm{~g} / \mathrm{L})$ and cefotaxime $(500 \mathrm{mg} / \mathrm{L})$.

Apical and axillary buds were blot dried in sterile filter paper and separately established on woody plant medium supplemented with B5 vitamins (Gamborg et al. 1976: myoinositol $100 \mathrm{mg} / \mathrm{L}$, nicotinic acid [free acid] $1 \mathrm{mg} / \mathrm{L}$, pyridoxine $\mathrm{HCl} 1 \mathrm{mg} / \mathrm{L}$, and thiamine hydrochloride $10 \mathrm{mg} / \mathrm{L}$ ), $15 \mathrm{~g} / \mathrm{L}$ sucrose, $37 \mathrm{mg} / \mathrm{L}$ cysteine, $7.2 \mathrm{~g} / \mathrm{L}$ Difco Bacto agar, and $0.25 \mathrm{mg} / \mathrm{L}$ 6-benzyladenine (BA) in $25 \times 150 \mathrm{~mm}$ borosilicate glass tissue culture tubes. The $\mathrm{pH}$ of the medium was adjusted to 5.8 with $1 \mathrm{M} \mathrm{NaOH}$. For meristems, the culture medium was supplemented with filter-sterilized spermidine $(200 \mathrm{mg} / \mathrm{L})$. Meristems were cultured either in solid or liquid medium with filter paper bridges to feed the explant by diffusion, while facilitating periodic renewal of the medium to avoid accumulation of phenolics. All cultures were incubated under cool fluorescent light at $25 \pm 2{ }^{\circ} \mathrm{C}$ and 33 to $45 \mu \mathrm{m} / \mathrm{m}^{2} /$ sec (16-hr photoperiod).

After six to eight weeks, elongated shoots were subcultured by individually transferring node cuttings (one bud and stem of $\sim 1.5 \mathrm{~cm}$ in length) to test tubes containing the same woody plant medium supplemented as described above, but without BA to allow rooting. Meristem cultures were subcultured on the same medium containing BA until active growth and elongation was observed, usually four to six months after establishment.

After at least three micropropagation cycles to increase the plant population, plantlets that were actively growing and had a normal appearance were tested for A. vitis using $\mathrm{MCH}-$ qPCR (Johnson et al. 2013). Figure 1 summarizes the different steps of the tissue culture therapeutics procedure developed to eliminate $A$. vitis from systemically infected grapes. Shoot explants were photographed with a Nikon D40 camera and a NIKKOR AF-S DX Micro 18-55 mm lens. Pictures of buds and meristems were taken with an Olympus SZX16 stereo microscope and a DP73 digital camera. 
Testing for $\boldsymbol{A}$. vitis by MCH-qPCR. Well-developed tissue culture-grown $V$. vinifera $\mathrm{cv}$. Riesling plantlets were transferred to sterile conical tubes and used to assay leaves, stems, and roots for $A$. vitis by MCH-qPCR. For every plantlet assayed, leaves, stems, and roots were dissected and separately tested as previously described (Johnson et al. 2013). Tissue culture back-ups of the plantlets that were negative for A. vitis were established in the greenhouse on Cornell mix in pots, as previously described (Alzubi et al. 2012), and grown at $20+/-5^{\circ} \mathrm{C}$ and $150 \mu \mathrm{m} / \mathrm{m}^{2} / \mathrm{sec}$. Once plants were actively growing in the greenhouse, they were monitored periodically for A. vitis by MCH-qPCR (Johnson et al. 2013).

Because of the variability observed in detection of $A$. vitis from the mother plants and tissue culture-generated plantlets, shoots of vines grown in the greenhouse were periodically cut back and repeatedly assayed over two consecutive years by MCH-qPCR. In 2017 and 2018, three sampling protocols were followed for every vine assayed for $A$. vitis: for sampling method A, six random nodes from two separate lignified shoots/vine were collected for assay; for sampling method B, three consecutive nodes from two separate lignified shoots/ vine (total six nodes/vine) were collected for assay five days after sampling A was done; and for sampling method C, a green shoot, including the shoot tip and six nodes and internodes below the tip, was assayed for each vine. Controls consisted of water and DNA from A. vitis strain S4. Tissue samples for MCH-qPCR testing were also collected from greenhouse-grown plants after one dormancy period of at least two months at $4 \pm 1{ }^{\circ} \mathrm{C}$. The elimination rate of $A$. vitis was determined by calculating the percentage of plants that tested negative for A. vitis in MCH-qPCR following the three sampling methods over the total number of plants tested following the therapeutics treatment and micropropagation.

\section{Results}

Presence of $A$. vitis in $V$. vinifera cv. Riesling mother vines. Cuttings of $V$. vinifera cv. Riesling vines with severe crown gall were collected in 2013 from a vineyard and grown

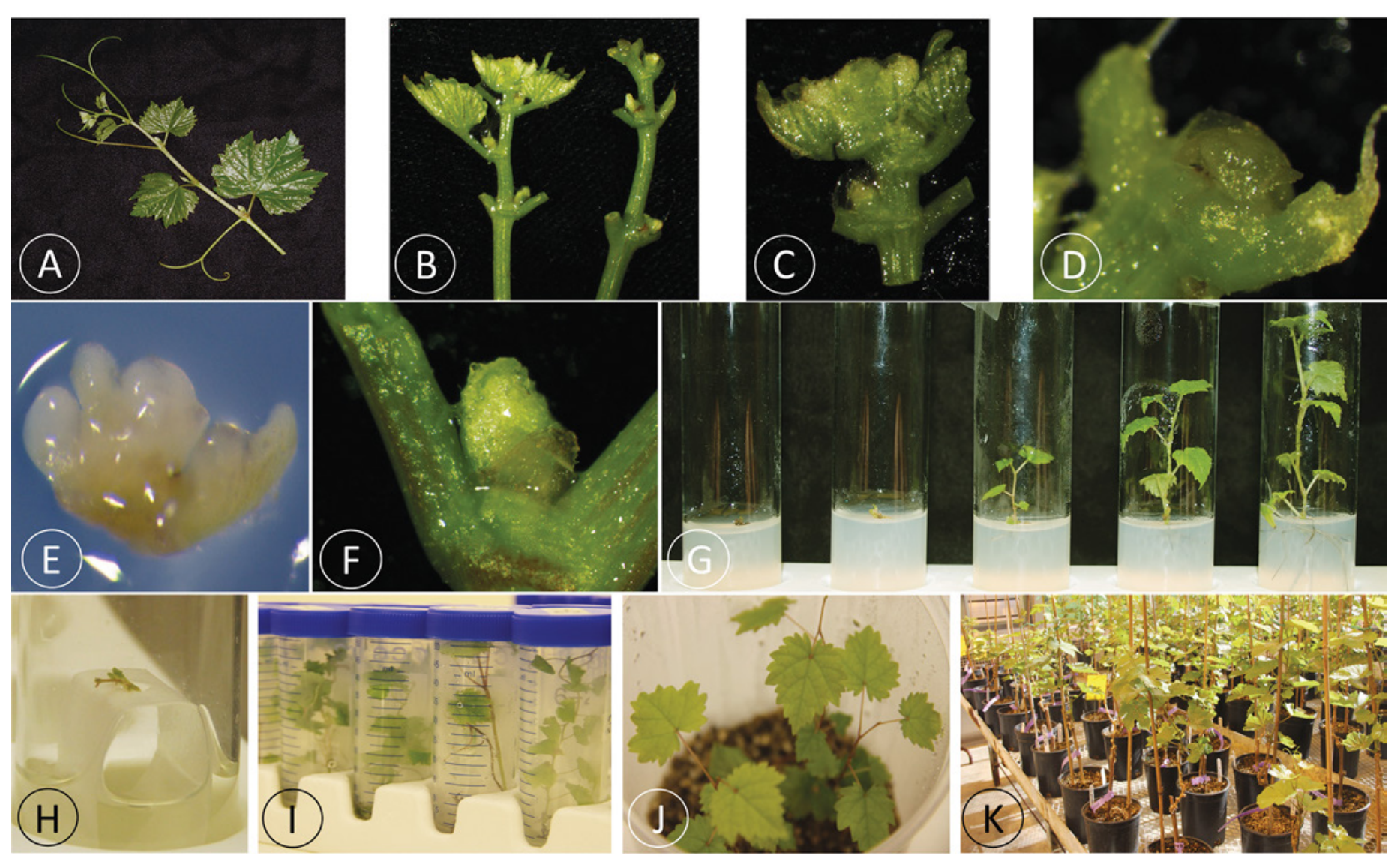

Figure 1 Procedure for elimination of Agrobacterium vitis from systemically infected grapes using tissue culture therapeutics. (A) Shoot tips collected from actively growing mother plants that were established in the greenhouse from cuttings of crown gall-diseased Vitis vinifera cv. Riesling. (B) Shoot tip explants (2 to $3 \mathrm{~cm}$ in length) prepared for excision of buds and meristems by first removing large leaves near the apex (left) and then all leaflets (right). (C) Shoot apex including apical and adjacent axillary buds. (D) Apical bud (0.5 cm in length) from which leaves were excised, ready for establishment on solid tissue culture medium. (E) Close-up of an apical meristem ( 0.3 to $0.5 \mathrm{~mm}$ diam) dissected for establishment in tissue culture medium. (F) Axillary bud $(0.5 \mathrm{~cm}$ in length) ready for establishment on solid tissue culture medium. (G) Different growth stages of apical and axillary buds after zero (left) to six (right) weeks of culture. (H) Meristem growing in liquid tissue culture medium on a filter paper bridge after 16 weeks in culture. (I) Plantlets were tested for $A$. vitis by magnetic capture hybridization in conjunction with real-time PCR (MCH-qPCR) after at least three subcultures onto fresh tissue culture medium. (J) Plantlets that tested negative for $A$. vitis were established in soil and grown in the greenhouse for further testing. (K) Actively growing plants in the greenhouse were tested for $A$. vitis using $\mathrm{MCH}-\mathrm{qPCR}$. 
in a greenhouse. The MCH-qPCR method was used multiple times to assay vines propagated from the cuttings for the presence of $A$. vitis. In 2014, shoot tips of 18 of the first 29 plants propagated (62\%) tested positive for $A$. vitis. Positive detections were made from shoot tips with meristems extracted and from shoot tips that included meristems (Johnson et al. 2016). When the same plants were cut back and regrown, only four of the $29(14 \%)$ were positive for $A$. vitis using MCH-qPCR. These results indicated the presence of $A$. vitis in mother vines that were used in this study for therapeutics experiments and verified an uneven distribution of the bacterium in the grapevine tissues.

A similar experiment was conducted in 2014 using a new set of 31 plants grown from cuttings taken from the same diseased $V$. vinifera $\mathrm{cv}$. Riesling vines. In this case, A. vitis was not detected in any of the meristems in two experiments (the second experiment involved evaluating the regrowth of the plants after they were cut back following the first set of assays). For shoot tips with the meristems removed, four tested positive (13\%) for A. vitis in MCH-qPCR in the first experiment, but none were positive in the second experiment (Johnson et al. 2016). Once again, these results indicated that A. vitis has an uneven distribution throughout infected vines, indicating that multiple samplings are required to confirm the presence of the bacterium in shoot tips from cuttings of systemically infected vineyard-grown plants.

Elimination of $\boldsymbol{A}$. vitis from diseased $\boldsymbol{V}$. vinifera $\mathrm{cv}$. Riesling vines. Shoot tip explants (five to six/plant) from 31 mother vines originating from cuttings taken from severely diseased $V$. vinifera $\mathrm{cv}$. Riesling, and actively growing in the greenhouse, were used to isolate apical and axillary buds and meristems (Figure 1). Explants from 14 of these 31 vines $(45 \%)$ were successfully established in tissue culture. Over 600 plantlets from the 14 established vines were micropropagated in tissue culture. Selected plantlets were transferred to Cornell mix based on preliminary negative MCH-qPCR testing for A. vitis using leaf, stem, and root samples. In 2016, 26 plantlets from four of the established vines in tissue culture (FR1, FR14, FR42, and FR47) were transferred to the greenhouse and tested for A. vitis using MCH-qPCR (Table 1). Although the bacterium was detected in five of the 26 vines generated from three of the four mother vines, the overall percentage of vines for which the bacterium was undetectable in 2016 was $81 \%$ (21 of 26) (Table 1). Additional plantlets from tissue culture that tested negative for A. vitis in $\mathrm{MCH}$-qPCR were transferred to soil in the greenhouse in 2017 (FR1, FR2, FR6, FR7, FR12, FR14, FR24, FR28, FR32, FR42, and FR47). A higher percentage of clean vines (96\%, 52 of 54) was obtained for these plants (Table 1).

Considering the variability of $A$. vitis detection in terms of pathogen distribution, further assays were done in 2017 and 2018. Plants were repeatedly trimmed back in the greenhouse and tissue from lignified and green shoots was collected using three different sampling protocols (A: six random nodes from two shoots; B: three consecutive nodes from two shoots; and C: six nodes and tip from a single shoot). Furthermore, after a dormancy cycle, plants were allowed to grow in the greenhouse and similarly trimmed back in 2018 for A. vitis testing. For all of the plants assayed in 2017 and 2018, two of $54(4 \%)$ in 2017 and none of $54(0 \%)$ in 2018 were found to be positive for A. vitis in MCH-qPCR, regardless of the sampling protocol or explant type (apical and axillary buds or meristems) (Table 1). These results could be explained by a successful pathogen elimination or a decline of $A$. vitis to below detectable levels.

\section{Discussion}

We showed that meristematic tissues of $V$. vinifera $\mathrm{cv}$. Riesling that are $A$. vitis free (or possess bacteria levels below the detection limit) can be successfully used for the production of pathogen-free vines by randomly collecting shoot tips from different mother plants. It is important to remove adjacent leaf tissue and reduce the size of the explant to utilize only the apical or the axillary bud with adjacent stem tissue $(\sim 0.5 \mathrm{~cm}$ in length) for successful establishment in tissue culture and pathogen elimination. If the meristem ( 0.3 to 0.5 $\mathrm{mm}$ ) is excised, it does take much longer for the generation of plantlets, and more technical skills are required compared

Table 1 Elimination of Agrobacterium vitis from crown gall-diseased Vitis vinifera cv. Riesling mother vines following tissue culture using apical and axillary buds or meristems.

\begin{tabular}{lccrrrr}
\hline \multirow{2}{*}{$\begin{array}{l}\text { Mother } \\
\text { vines }\end{array}$} & \multicolumn{5}{c}{$\mathbf{2 0 1 6}^{\mathrm{a}}$} & \multicolumn{5}{c}{$\mathbf{2 0 1 7}^{\mathrm{b}}$} & \multicolumn{2}{c}{$\mathbf{2 0 1 8}^{\mathrm{c}}$} \\
\cline { 2 - 7 } FR42 & $12 / 14$ & $(87 \%)$ & $14 / 14$ & $(100 \%)$ & $14 / 14$ & $(100 \%)$ \\
& & & $10 / 10$ & $(100 \%)$ & $10 / 10$ & $(100 \%)$ \\
FR1 & $5 / 6$ & $(83 \%)$ & $6 / 6$ & $(100 \%)$ & $6 / 6$ & $(100 \%)$ \\
& & & $3 / 3$ & $(100 \%)$ & $3 / 3$ & $(100 \%)$ \\
FR47 & $3 / 3$ & $(100 \%)$ & $3 / 3$ & $(100 \%)$ & $3 / 3$ & $(100 \%)$ \\
& & & $2 / 2$ & $(100 \%)$ & $2 / 2$ & $(100 \%)$ \\
FR14 & $1 / 3$ & $(33 \%)$ & $3 / 3$ & $(100 \%)$ & $3 / 3$ & $(100 \%)$ \\
& & & $1 / 1$ & $(100 \%)$ & $1 / 1$ & $(100 \%)$ \\
FR2 & na & & $1 / 2$ & $(50 \%)$ & $2 / 2$ & $(100 \%)$ \\
FR6 & na & & $1 / 1$ & $(100 \%)$ & $1 / 1$ & $(100 \%)$ \\
FR7 & na & & $1 / 1$ & $(100 \%)$ & $1 / 1$ & $(100 \%)$ \\
FR12 & na & & $2 / 3$ & $(67 \%)$ & $3 / 3$ & $(100 \%)$ \\
FR24 & na & & $3 / 3$ & $(100 \%)$ & $3 / 3$ & $(100 \%)$ \\
FR28 & na & & $1 / 1$ & $(100 \%)$ & $1 / 1$ & $(100 \%)$ \\
FR32 & na & & $1 / 1$ & $(100 \%)$ & $1 / 1$ & $(100 \%)$ \\
Total & $21 / 26$ & $(81 \%)$ & $52 / 54$ & $(96 \%)$ & $54 / 54$ & $(100 \%)$ \\
\hline
\end{tabular}

aNumber of plants that tested negative in magnetic capture hybridization in conjunction with real-time PCR (MCH-qPCR) over the total number of plants indexed for $A$. vitis by $\mathrm{MCH}-\mathrm{qPCR}$ following apical or axillary bud or meristem culture and micropropagation. The percentage of plants that tested negative for $A$. vitis in MCH-qPCR is in parentheses. Plants were transferred to soil on 7 Oct 2015, and tested on 18 May 2016. Plantlets of lines FR3, FR4, and FR9 were not established in soil in the greenhouse because they did not grow well in tissue culture. na: not applicable.

${ }^{b}$ Additional plants were transferred from tissue culture to soil on 7 Jan 2017. These plants and those transferred to soil in 2016 were repeatedly trimmed back in 2017 for retesting of the new growth by MCH-qPCR.

cPlants established in 2016 were subjected to a dormancy cycle in 2017, grown in the greenhouse, and repeatedly trimmed back in 2018 like those transferred to soil in 2016 and 2017 for retesting by $\mathrm{MCH}-\mathrm{qPCR}$. 
to the handling of apical and axillary buds, as excess phenolic compounds released during tissue manipulation can easily kill the explants. To address this challenge of meristem cultures, successive transfers are needed to new media at short time intervals in conjunction with the use of antioxidants. Although transfers can be reduced by the use of liquid medium with filter paper bridges, these extra steps make meristem culture less routine than the use of apical or axillary buds excised from shoot tips. In both cases, however, the use of antioxidants (e.g., cysteine), both in sterile water during isolation of the explants and in the establishment medium, is critical to reduce damage to the tissue by phenolic compounds released during excision. A short cold treatment of the shoot tip explants (24 to $48 \mathrm{hr}$ at $4^{\circ} \mathrm{C}$ ) prior to excision of the buds and meristems is also beneficial to reduce the release of phenolic compounds that brown and kill the explant (Yepes et al. unpublished). Additionally, the use of antibiotics (e.g., carbenicillin and cefotaxime) during establishment to kill any bacteria released that may be systemically present in the tissue is also beneficial.

The determination that $A$. vitis may be detected in a portion of the grape plants produced in tissue culture is consistent with previous findings (Poppenberger et al. 2002). Additionally, we have shown that the bacterium can persist on surfaces of grape leaves, thus epiphytically on grapevines (Orel et al. 2017). It is important to note that we were unable to detect the bacterium from vines maintained in the greenhouse for one to two growing seasons following therapeutics treatment. This could result from pathogen elimination over time or from a decline of $A$. vitis populations below detectable levels. It is worth noting that sampling was done to include multiple nodes and internodes, as well as different regions of the vines, to improve chances of detecting $A$. vitis. In spite of extensive sampling and testing, the bacterium remained undetectable by MCH-qPCR after two growing seasons.

Microshoot tip culture is an effective method for the elimination of viruses from infected grapevine selections (Golino et al. 2017). We now have demonstrated that apical and axillary buds, as well as meristems, are also efficient for the elimination or a reduction below detectable levels of $A$. vitis. It is important for successful production of clean vines to test the health status of plants obtained through the therapeutics process after one or two dormancy periods. This is critical to address situations for which the pathogen remains below the detection threshold. This approach was successfully applied in this study to show that $A$. vitis remained undetectable by $\mathrm{MCH}-\mathrm{qPCR}$ in vines derived from apical and axillary buds, as well as meristem cultures, that were subjected to one dormancy cycle.

MCH-qPCR has been used to determine the distribution of $A$. vitis in grapevines (Johnson et al. 2016), and to demonstrate the presence of the bacterium in wild grapevines and in association with dormant buds and grape leaves in vineyards (Burr et al. 2016, Orel et al. 2017). The MCH-qPCR method used in this study confirmed the uneven distribution of $A$. vitis in infected plants. A digital droplet PCR (ddPCR) was recently developed and employed to demonstrate the quantitative presence of $A$. vitis in association with grape roots and rhizosphere soils (Voegel and Nelson 2018). Using the ddPCR method, different levels of infection were shown to be associated with vines propagated in nurseries from different regions of North America (Voegel and Nelson 2018). Employment of MCH-qPCR and ddPCR, two sensitive and specific A. vitis detection methodologies, has greatly increased our understanding of $A$. vitis biology and has the potential to answer additional questions on the ecology of crown gall that will lead to improved disease management (Burr et al. 2016, Kuzmanović et al. 2018).

The production and use of clean grapevine propagation material is vital for the establishment of vineyards, particularly foundation vineyards (Golino et al. 2017). For instance, clean, A. vitis-tested vines at foundation vineyards maintained by research institutions, governmental agencies, or nurseries should serve as a source of cuttings for the multiplication of rootstock genotypes and scion cultivars, and subsequently, for the production of planting material. We speculate that having undetectable levels of $A$. vitis in vines prior to planting vineyards will control the early onset of crown gall. Because young vines are particularly vulnerable to damage from crown gall, the ability to manage the disease in the first years following establishment in a vineyard will have a positive effect on the productive lifespan of the vineyard (Burr et al. 2016, Kuzmanović et al. 2018). Although few studies have been done on the effect of crown gall infections on vine growth and yield, the extent of galling in relation to trunk diameter was reported to have a direct impact on vines (Schroth et al. 1988). The use of clean vines for which the level of $A$. vitis is undetectable should be beneficial to foundation vineyards, nurseries, and production vineyards alike.

\section{Conclusion}

Elimination of $A$. vitis was achieved from severely infected $V$. vinifera $\mathrm{cv}$. Riesling vines by culturing apical and axillary buds and meristems from shoot tips of greenhouse-grown plants followed by micropropagation in tissue culture. Plants recovered had undetectable bacterial populations following repeated and extensive testing by $\mathrm{MCH}-\mathrm{qPCR}$, a very sensitive detection method, even after a dormancy period. Given the negative impact of $A$. vitis on severely infected vines and the lack of management strategies, it is anticipated that the production and use of clean grapevines in vineyards is important to delay the early onset of crown gall and contribute to vineyard productivity.

\section{Literature Cited}

Alzubi H, Yepes LM and Fuchs M. 2012. Enhanced micropropagation and establishment of grapevine rootstock genotypes. Int Journal of Plant Developmental Biology 6:9-14. http://www.globalsciencebooks. info/Online/GSBOnline/images/2012/IJPDB 6(1)/IJPDB 6(1)9-14o. pdf.

Bazzi C, Stefani E, Gozzi R, Burr TJ, Moore CL and Anaclerio F. 1991. Hot-water treatment of dormant grape cuttings: Its effects on Agrobacterium tumefaciens and on grafting and growth of vine. Vitis 30:177-187.

Burr TJ, Katz BH, Bishop AL, Meyers CA and Mittak VL. 1988. Effect of shoot age and tip culture propagation on grapes on systemic 
infestation by Agrobacterium tumefaciens biovar 3. Am J Enol Vitic 39:67-70.

Burr TJ, Ophel K, Katz BH and Kerr A. 1989. Effect of hot water treatment on systemic Agrobacterium tumefaciens biovar 3 in dormant grape cuttings. Plant Dis 73:242-245.

Burr TJ, Reid CL, Splittstoesser DF and Yoshimura M. 1996. Effect of heat treatments on grape bud mortality and survival of Agrobacterium vitis in vitro and in dormant grape cuttings. Am J Enol Vitic 47:119-123.

Burr T, Johnson K, Reid C, Canik Orel D, Yepes M and Fuchs M. 2016. Environmental sources of Agrobacterium vitis, the cause of crown gall on grape. New York Fruit Quarterly 24:15-18.

Cassells AC. 2012. Pathogen and biological contamination management in plant tissue culture: Phytopathogens, vitro pathogens, and vitro pests. Methods Mol Biol 877:57-80.

Dula T, Kölber M, Lázár J and Szegedi E. 2007. Production of healthy grapevine propagating material: Pathogens and methods. http://www.winetwork-data.eu/intranet/libretti/0/libretto15606-01-1. pdf.

Gamborg OL, Murashige T, Thorpe TA and Vasil IK. 1976. Plant tissue culture media. In Vitro 12:473-478.

Golino DA, Fuchs M, Sim S, Farrar K and Martelli G. 2017. Improvement of grapevine planting stock through sanitary selection and pathogen elimination. In Grapevine Viruses: Molecular Biology, Diagnostics and Management. Meng B et al. (eds), pp. 561-579. Springer, Cham.

Johnson KL, Zheng D, Kaewnum S, Reid CL and Burr T. 2013. Development of a magnetic capture hybridization real-time PCR assay for detection of tumorigenic Agrobacterium vitis in grapevines. Phytopathology 103:633-640.

Johnson KL, Cronin H, Reid CL and Burr TJ. 2016. Distribution of Agrobacterium vitis in grapevines and its relevance to pathogen elimination. Plant Dis 100:791-796.
Kuzmanović N, Pulawska J, Hao L and Burr TJ. 2018. The ecology of Agrobacterium vitis and management of crown gall disease in vineyards. In Agrobacterium Biology. Current Topics in Microbiology and Immunology, vol 418. Gelvin S (ed.), pp. 15-53. Springer, Cham.

Maliogka V, Martelli GP, Fuchs M and Katis N. 2014. Control of viruses infecting grapevine. In Control of Plant Viruses, Advances in Virus Research. Loebenstein G and Katis N (eds.), pp. 91:175-227. Elsevier.

Moyer MM and Grove G. 2014. "Crown Gall” in Field Guide for Integrated Pest Management in Pacific Northwest Vineyards. Moyer MM and O'Neal SD (eds.). Pacific Northwest Extension Publication \# PNW644. Pullman, WA. http://cru.cahe.wsu.edu/CEPublications/ PNW644/PNW644.pdf.

Orel DC, Reid CL, Fuchs M and Burr TJ. 2017. Identifying environmental sources of Agrobacterium vitis in vineyards and wild grapevines. Am J Enol Vitic 68:213-217.

Poppenberger B, Leonhardt W and Redl H. 2002 Latent persistence of Agrobacterium vitis in micropropagated Vitis vinifera. Vitis 41:113-114.

Schroth MN, McCain AH, Foott JH and Huisman OC. 1988. Reduction in yield and vigor of grapevine caused by crown gall disease. Plant Dis 72:241-246.

Sim ST and Golino D. 2010. Micro- vs. macroshoot tip tissue culture therapy for disease elimination in grapevines. Foundation Plant Services Grape Program Newsletter, October, pp. 12-15. http:// fpms.ucdavis.edu/WebSitePDFs/Newsletters\&Publications/GrapeNewsletter10.pdf.

Voegel TM and Nelson LM. 2018. Quantification of Agrobacterium vitis from grapevine nursery stock and soil using droplet digital PCR. Plant Dis 102:2136-2141.

Wample RL, Bary A and Burr TJ. 1991. Heat tolerance of dormant Vitis vinifera cuttings. Am J Enol Vitic 42:67-72. 